\title{
LEARN FROM PONDOK PESANTREN AS THE MEANS FOR BUILDING YOUNG MUSLIMS GENERATION'S IDENTITY
}

\author{
Aruni Chaerunisa ${ }^{1}$ \\ Faculty of Psychology, \\ Universitas Airlangga (UNAIR), Indonesia \\ (Email: aruni.chaerunisa-2017@psikologi.unair.ac.id) \\ Firda Arifatu Rizkia ${ }^{2}$ \\ Faculty of Pharmacy, \\ Universitas Airlangga (UNAIR), Indonesia \\ (Email: firda.arifatu.rizkia-2017@ff.unair.ac.id) \\ Nada Firdaus ${ }^{3}$ \\ Faculty of Pharmacy, \\ Universitas Airlangga (UNAIR), Indonesia \\ (Email: nada.firdaus-2017@ff.unair.ac.id)
}

Accepted date: 19-01-2019

Published date: 07-07-2019

To cite this document: Chaerunisa, A., Rizkia, F. A., \& Firdaus, N. (2019). Learn from Pondok Pesantren as The Means for Building Young Muslims Generation's Identity. International Journal of Education, Psychology and Counseling, 4 (31), 75-86.

DOI: $10.35631 /$ IJEPC.431008

\begin{abstract}
Education is the need of every human being. Education is useful for developing self-potential. One form of education in Indonesia is the education of Islamic boarding schools as known as Pondok pesantren. Pondok Pesantren do not only teach education at schools in general but also integrate the knowledge of Islam religion in the education system. Nowadays, the condition of young Muslims is very alarming due to the inability to face the flow of globalization and thus losing its Muslim identity. As the result, there is a moral decline that leads to deviant behavior, especially concerning Islamic values. To overcome this problem, Pondok Pesantren education can be a solution. In this study two samples of famous Pondok Pesantren in Indonesia were taken, namely Pondok Modern Darussalam Gontor and Pondok Pesantren Sidogiri. We use literature study methods from various journals that discuss the importance of Pondok Pesantren. As a step to deepen the material, an interview was held with an Ustadz (Islamic religious teacher) who had conducted research at various Pondok pesantren in Indonesia. The results of this study, obtained 3 values and teaching lifestyles that can be applied from Pondok Pesantren, namely the formation of identity, sensitivity to society, and efforts to make changes in society without losing identity. The two Pondok Pesantren teach the formation of a good identity to their santri (students of pesantren) so that they are not easily carried away by the negative effects of globalization. In addition, it also teaches how to behave socially in the community so that they can apply the knowledge gained in Pondok Pesantren and become agents of change in people's lives. Thus, the education system of Pondok Pesantren can be used as a means of forming the identity of young Muslims as a provision to face the current of globalization.
\end{abstract}


Keywords: Young Muslims Generation, Pondok Pesantren, Identity

\section{Introduction}

\section{Education in Indonesia}

Education is one of the most important need for humans. According to the Undang-Undang Republik Indonesia Nomor 20 Tahun 2003 Tentang Sistem Pendidikan Nasional (constitution of the Republic of Indonesia about national education), education is a conscious and planned effort to create learning atmosphere and learning process for students to actively develop their potency to have spiritual power of religion, self-control, personality, intelligence, noble character, and skills needed by him (her) and the community (Indonesia, 2003). The benefits obtained by education include getting knowledge that is not known before, developing one's potential, and can form the next generation of the nation.

Indonesia is one of the countries in the Southeast Asia region, with a population of around 265,015,000 (BPS-Statistic Indonesia, 2018). The large number of Indonesian people, various characters and cultures, create various types of education. Education in Indonesia itself is divided into two, formal and non-formal education. Formal education is education in schools that are obtained regularly, systematically and multilevel, consist of elementary, middle and high school. Whereas non-formal education is education other than formal education which is carried out in a structured and multilevel, one of this education is Islamic boarding schools as known as pondok pesantren.

\section{Pondok Pesantren Education in Indonesia}

Indonesia is a country with the largest Muslim population in the world, with an amount of around 207,176,162 (BPS-Statistic Indonesia, 2018). The large number of Muslim population is inseparable from the role of the da'i and the muballigh who spread Islam since the 14th century. On one of Indonesia's largest islands, Java, there were Walisongo, the most known 9 da'i who first spread Islam in the land of Java. They all spread Islam in different areas, using kind methods, so that the Indonesian people could easily accept what the Walisongo was preaching.

One of the ways done by the Walisongo in the spread of Islam is by building Pondok pesantren (Islamic boarding schools). Walisongo established educational institutions like this to prepare educated cadres to continue the struggle to spread Islam in Indonesia. Pondok pesantren are built as centers for people who want to learn and explore Islam, to be practiced on their own, so that they can become better people and be practiced by others so that they can change the surrounding environment for the better.

Pondok pesantren come from two words, namely pondok and pesantren. The pondok itself comes from Arabic, which is "funduq" which means a large dormitory which is provided for a stopover. The pesantren itself is etymologically derived from the words santri, who get prefix pe- and the suffix -an so that they become pe-santri-an with the word "shastri" which means student (Dhofier, 2009). From these two words, defined that Pondok pesantren are educational and religious institutions whose students live together and study under the guidance of teacher better known as the Kyai and have a dormitory for students to stay at. In the book "Pesantren Tradition" by Zamakhsyari Dhofier states "Pondok, mosques, santri, the 
teaching of classical Islamic books and Kyai are the five basic elements of the pesantren tradition".

Pondok pesantren education is very important in this era of globalization, where it is so easy to access all information by various groups, especially young Muslim generation. Since childhood, most of them have become accustomed to using gadgets and accessing things that not just the positive, but also things that have negative value and impact. It's common for them to use their time to interact more with gadgets (playing games or socializing the media) rather than study or doing other useful things. The effects are that they become lazy and do not care about the environment or society. Therefore, the role of pondok pesantren becomes very important to prevent these things from happening.

What distinguishes education in pondok pesantren with other schools? There are noble values that may not being taught outside the boarding school which will have a very good impact for students. Among them are time discipline. The density of activities in pondok pesantren that have already been scheduled, urge students to complete all activities quickly and precisely, so that there are no lazing or waste of free time. There is also a tawadhu or humble attitude towards the teacher. Santri are educated to treat the teacher well, with courtesy and polite attitude, as they treats their own parents, because the teacher is their parents while they are in the boarding school. Other attitudes, mutual respect and sensitivity to the surrounding environment. Living with hundreds or even thousands people in one environment, santri trained to respect and help each other in order to create the best, comfortable and conducive learning environment.

In general pondok pesantren in Indonesia consist of two types, traditional and modern. Traditional pondok pesantren or salaf are Islamic boarding schools which focus in the study of Islamic religion, conducted individually or in groups with a concentration on classical Arabic books (Setyaningsih, 2016). The levels is not based on a unit of time but based on the completion of the book that being studied. While modern pondok pesantren organize educational activities with a modern approach through formal education units, both madrasas (MI, MTS or MA) and schools (elementary, junior high, high school) or other names with a classical approach. Learning is carried out in stages and continuously by time period.

Based on the Statistik Pendidikan Islam Tahun Pelajaran 2014/2015 published by the Directorate General of Islamic Education at the Ministry of Religion, the number of Islamic boarding schools in Indonesia is 28,961 with a total of 4,028,660 students (Ministry of Religious Affairs of Indonesia, 2016). Among the thousands of existing Islamic boarding schools, there are 2 Islamic boarding schools that are very well-known both in Indonesia and abroad, so it is not surprising that many people from outside Indonesia come to study Islamic religion and conduct research. The two pondok pesantren are the Pondok Modern Darussalam Gontor dan Pondok Pesantren Sidogiri.

\section{Pondok Modern Darussalam Gontor and Pondok Pesantren Sidogiri}

Each pondok pesantren has its own characteristics. This can be seen from the vision and mission and how the system runs on the boarding. There are 2 Islamic boarding schools which are used as the material of this study, which are considered representative in demonstrating the role and synergy of Islamic boarding schools in Indonesia, namely the Pondok Modern Darussalam Gontor dan Pondok Pesantren Sidogiri. Pondok Modern Darussalam Gontor is unique in educating its students especially in the field of language. With Moden-based, Gontor uses the classic book in its teaching and education unlike Pondok 
Pesantren Sidogiri which is still thick with traditional learning systems. Although the two boarding have different perspectives, the two boarding can produce alumni who are not only thoughtfully intelligent but also able to provide benefits to the community.

Pondok Modern Darussalam Gontor or commonly called Gontor is the largest boarding school in Indonesia, located approximately $3 \mathrm{~km}$ east of Tegalsari and $11 \mathrm{~km}$ to the southeast from the city of Ponorogo, East Java, Indonesia (Fasa, 2017). Gontor used to be a forest area that not many people came to. Even this forest was used as a hiding place for robbers, criminals, drunks or thieves. However, since 1926 the Committee has begun to switch functions in the hands of a reformer of Islamic education, K.H Achmad Sahal, K.H Zainuddin Fananie and K.H Imam Zarkasyi or commonly known as Trimurti (Alhamuddin, 2005). Trimurti is a term that describes the unity of ideas, ideals and steps of the struggle. The three founders have a role as a determinant of the direction of Gontor's Modern Cottage. In the growth and development of Gontor Pondok Modern, Trimurti has their respective roles, including K. H. Ahmad Sahal acting as a caregiver, K.H. Zainuddin Fananie as an intellectual figure who is very influential in the intellectual journey of the pondok pesantren, and K.H. Imam Zarkasyi has more role as educator. Gontor as a modern boarding school can also be understood, from the educational background of the founding figures of Pondok Modern Darussalam Gontor, where all three of them have received Islamic education in the form of traditional Islamic boarding schools as well as modern Western education brought by Dutch colonizers, this experience is quite important for education providers in the Pondok Modern Darussalam Gontor. On one hand, this institution excels in the world of boarding schools with their souls and a dormitory system that places students for 24 hours in a conducive environment, designed for education. On the other hand, modern Western education with its methodology is considered efficient, effective and systematic in transforming knowledge to students. In addition Trimurti also tried to integrate the two systems into the education system in the Pondok Modern Darussalam Gontor they founded.

In integrating these two systems into the education system, Gontor conceptualized education in 3 fields, namely the integration of the madrasa education system and the pesantren system, foreign languages as the key to science, and school day with a dormitory system. The activities in Pondok Modern Darussalam both the madrasa system and the pesantren system are interrelated. In addition to being supported by an interrelated system, Gontor familiarizes santri to use foreign languages in everyday conversation. By habituating the use of foreign languages and planting the importance of foreign languages to their santri, they will open up the treasures of science, religion and the public. In order to create a conducive islamic boarding schools life, Gontor created an atmosphere of discipline, where students were trained to be disciplined in participating in existing programs. In addition to seeing from the founder's point of view, Gontor has a motto that is used as a reference, namely "Gontor stands above and for all groups". This shows that the education and teaching in Gontor is not exclusively for children from great family status. But education and teaching are available for all upper, middle and lower classes. Pondok Modern Darussalam Gontor is also owned by the people, not the property of one group. Gontor began to be used as a means for students who wanted to gain religious and formal knowledge. Not only that the gontor is also famous for the pesantren which has the application of high discipline and timeliness in carrying out daily activities, the use of foreign languages (Arabic and English) which are closely monitored and have a very strong alumni network. Based on the vision as an educational institution that prints the leaders' cadres, it becomes a place of worship for the Talab al-ilmi (those who seek for knowledge) and becomes a source of Islamic knowledge, Qur'anic language and science while still having the spirit of Islamic boarding schools. Gontor has 
been able to produce many national figures. For example KH Hasyim Muzadi who once served as the former chairman of the Nahdhatul Ulama PB (NU), Hidayat Nur Wahid who served as deputy chairman of the Republic of Indonesia MPR and many other national figures.

The second Pondok pesantren that was used as a reference in this study was the Pondok pesantren Sidogiri, which is a famous Pondok pesantren in Pasuruan, East Java as an advanced salaf boarding school in the teaching of yellow books. In addition, the Sidogiri Islamic Boarding School is also noted as the most successful independent boarding school in developing the economy of Islamic boarding schools that have a monthly income of tens of billions. In the system of developing the economy in Islamic boarding schools, the system used starts from serving the needs of the community and seeing how the condition of the community is located around the Pondok Pesantren Sidogiri. Baitul Mal wat-Tamwil Maslahah Mursalah lil Ummah or commonly called the BMT Cooperation is one of the works of the sidogiri boarding school. There is BMT Cooperation because it was initiated by alumni of Pondok pesantren Sidogiri. The establishment of BMT Cooperation is expected to have a significant influence on the community economy. By definition there are two main functions of the BMT Cooperation, namely:

1. Baitul Tanwil (property development house), conducts productive business development activities and investments in improving the economic quality of micro and small entrepreneurs by, among others, encouraging savings activities and supporting the financing of economic activities.

2. Baitul Maal (treasure house), receiving zakat, infaq, and alms funds and optimizing its distribution in accordance with the regulations and mandate (Mahbub, 2016).

From the two functions that have been mentioned, it can be concluded that BMT is a supporting institution for lower and smaller community economic activities based on the sharia system, which has the aim of improving the quality of economic enterprises for the welfare of the community and business, independent, and self-developed managed professionally. Whereas in terms of Baitul Maal, it is more directed at collecting and distributing non-profit funds, such as zakat, infaq, and sodaqoh.

\section{Habits of Gontor's dan Sidogiri's Santri}

Each educational institution certainly has a prominent vision and mission from each of its institutions. This also relates to the Pondok Modern Darussalam Gontor and Pondok Pesantren Sidogiri. Both of them have their own characteristics. In terms of the education system used, the Pondok Modern Darussalam Gontor implements a system of modern Islamic boarding schools by prioritizing the intelligence of the mindset and discipline of the santri. Whereas in Pondok Pesantren Sidogiri, the system applies a salaf pesantren wherein it still contains traditional values taught by pesantren. In addition the pesantren also teaches students to behave sensitively towards the environment and surrounding communities by helping in fulfilling their economic needs

Internally Pondok Modern Darussalam Gontor is an Islamic educational institution that implements a modern system in its teaching where the entire life of the islamic boarding school is a medium of santri education with high discipline. The education system is integrated, integrating intra-pesantren, extra-pesantren and co-curriculum. Faith and knowledge are obtained through teaching in pesantren and in the family and then practiced in community life. 
Pondok Pesantren Sidogiri is an islamic boarding school that still organizes education with a salaf system. In teaching, the santri pursue the yellow book as a reference. Pondok Pesantren Sidogiri does not blend with modernity, it firmly maintains the traditional value of the salaf. The curriculum of the Pondok Pesantren Sidogiri allows the santri to maintain their social identity in actualizing their existence amidst the demands of the community. noble and beneficial to the surrounding community.

Pondok Pesantren Sidogiri also teaches students to be entrepreneurial (Rofiq, 2017). With capital value independence and development of life skills, santri are expected to be able to manage the economic aspects of the pondok pesantren. There are several examples of entrepreneurship developed by santri namely "Santri" drinking water production. BMT, waste management, training centers for economic strengthening and entrepreneurship. The process of entrepreneurship education is considered important because when students enter the community, santri will have the provision of the ability to become entrepreneurs so that they are not dependent on others. In the entrepreneurship education system, education providers do not make profit a top priority but rather train lifeskill and character formation. In the formation of character, the teachers educate with the heart, educate slowly with patience and patience so that the character of siddiq and trust is formed which leads to the attitude of tawadhu in the santri.

Entrepreneurship values are internalized in the Sidogiri Islamic boarding school based on worship, where all economic activities carried out are intended to worship Allah SWT. The value of worship is centered on faith, the higher a person's faith, the better the management of economic institutions and the thicker the spirit of entrepreneurship. In the end, students are expected to help the surrounding communities who need help, also as a form of preaching to the community.

\section{Pondok Pesantren Teaching as a Solution for the Establishment of Young Muslim Generation Identities}

The issue of this study is deviation of our young Muslims generation identity, especially regarding to Islamic values. The problem arose because of the education and the environment is not conducive in forming a good Muslim identity. We can look at the reality, how western and American culture emphasizes individual autonomy and secular values which are often not in line with the more traditional cultures with values of community adherence and obedience to religion. So the challenge is how to shape the cultural identity of the younger generation of Muslims in facing globalization by focusing on the moral and other religious issues (Jensen, 2003).

The formation of good identity is one of the important values that can be a solution to improve the younger generation. In forming identity, Pondok pesantren apply comprehensive teaching, where everything that santri gets is a form of education. In addition, with the teaching of Islamic boarding schools about exemplary, the formation of the Muslim identity of the young generation can be directed as it should.

Pondok pesantren construct islamic lifestyle that produce values that can be the solution to the recent problems of the young generation. In this case we refer to the values applied in the daily lives of santri in the Pondok Modern Darussalam Gontor and Pondok pesantren Sidogiri. From the various values that we have, we specialize in our discussion of 3 values, the formation of good identity, sensitivity and caring for society, and efforts to make changes in society without losing identity. 
Sensitivity and caring for society are a value that must be maintained amid the problem of individualism. The founders realized how wrong it would be if Islamic boarding schools taught Islamic Shari'a but did not have any impact on the surrounding area, instead allowing Sharia violations to occur. Then the students are taught and encouraged to be critical of the problems and needs of the community as part of the party that should receive the benefits of the existence of Islamic boarding schools.

Efforts to make changes in society without losing identity can be a solution to how young Muslims should spread benefits on the earth. In Islamic boarding schools, santri taught how to provide maximum benefit for people, seek knowledge to wherever as far as possible, and work in any field after completing education, while maintaining the Islamic values that have been obtained and the Muslim identity they have. Santri was encouraged to enter and work into the society while wearing his santri clothes and good morality, as well as manners. In Indonesia, we can say it as mewarnai tanpa diwarnai (to give color without being colored).

The objective of this study is to extract the values that can be learned from pondok pesantren teaching and formulate the aplication of the values. What are needed by the young Muslims generation, what are provided and taught in pondok pesantren, and how do we transform the values into aplication.

This study uses the literature review method and discussion with several informants. The informants were choosen by snowball sampling, which the first informant was an ustadz who was also an alumnus of Airlangga University that expertize in islamic studies. The ustadz then gave recommendation to find primary resource person at the Indonesia Sharia Economic Festival (ISEF) 2018 in Pondok pesantren section at Grand City Mall Surabaya, Indonesia. Three main informants were selected, an alumnus from Pondok Modern Darussalam Gontor, an ustadz from Pondok Modern Darussalam Gontor, and an alumnus as well as an ustadz who work at publishing company at the Pondok pesantren Sidogiri. The discussion was held on Friday night December 142018 in the location. The other main informants is one of the alumni of the Gontor Putri Modern Islamic Boarding School named Annisa Aulia Salsabila who is now continuing her studies at the Muhamadiyah University in Sidoarjo, an associate of one of the co-author. The data obtained were analyzed using descriptive analysis, all data were organized, interpreted, linked and combined along the process of research from the beginning of data collecting until the final process of result and conclusion.

\section{Literature Review}

In this paper, some theories regarding identity and islamic teaching in pondok pesantren, that can be adopted into values and practices as the means for building young Muslims generation's identity, is used. The main theory of identity, is discussed based on Santrock (2011) theory of identity and human development. Islamic teaching in pondok pesantren, mainly discussed based on information that was aquired from primary and secondary resource people. There are also some studies that used as references to support the discussion.

Identity is a self-description consisting of several pieces including career identity, politics, religion, relationships, intellectual, sexual, ethnic, interests, personality, and physical. Important issues regarding identity occur mostly in adolescence, but the formation of one's own identity does not begin or finish at this stage. The important thing in the development of identity in adolescence is how physical, cognitive, and socio-emotional progress reach the stage where adolescents can sort and shape their childhood identities and then identify and develop the direction of life that leads to maturity in adulthood (Santrock, 2011). 
Below are the discussion of the values learned from pondok pesantren teaching that can be applied as the means for building young Muslims generation's identity.

\section{The Formation of Good Identity}

\section{Comprehensive Teaching}

According to Ibn Maskawaih (1994), identity is a type of human that always leads to a noble character and behavior and glory, that all human life should be dedicated to obtaining virtue through its actions (Santoso, 2013). The formation of identity in a person should be planted early through the family environment and supported by education. In the process of forming identity, religious values need to be inserted which emphasize moral improvement. Therefore moral and moral formation needs to be included in education. Thus the output of education is not only limited to intellectual values but also good ethical values. One alternative education that teaches both of these values is Islamic Boarding School

Pondok Modern Darussalam Gontor can be used as an educational reference. Gontor instills the value of discipline by involving all elements of the educator so that all what is seen, what is heard, and what is felt by the students all have an educational element. The modern roots of the Pondok Modern Darussalam Gontor have been seen since the founders of Trimurti established this pesantren, through a teaching system that combines all elements of education. From the time the santri woke up to sleep again all of them had educational values. Santri are in a dormitory for 24 hours in an environment designed for education with supervision and guidance from the Kyai.

\section{Exemplary}

Sidogiri Islamic Boarding School is one of the salafiyah Islamic boarding schools, meaning that the lodge focuses on learning about classic yellow books, such as the book Ta'limul Muta'allim by Syaikh Az-Zarnuji. The book is a 'compulsory' book for students of Pondok Pesantren Sidogiri because the book contains about the guiding principles of knowledge, both adab to knowledge and the teacher who delivers knowledge, so that the person is expected to have a tawadhu attitude or humble teacher and respect for the knowledge be delivered. The teacher who teaches it is not just 'teaching', but he also practices it so that it can be an example for the santri.

\section{Sensitivity and Caring for Society}

Along with the development of the times many of the social values left by some people, one of which is sensitivity and caring. Indications of a weakening of social sensitivity and caring where people are individualistic or in other words more concerned with personal interests than mutual interests. In daily life individualists can be exemplified by someone who is knowledgeable but there is no willingness to apply it in community life and still selfish.

With the deterioration of sensitivity and caring among people has an impact on the mindset and pattern of action. Therefore, in increasing public awareness early training needed, where children are still easy to receive teaching. So when they grow up, the child will be easier to apply in socializing in the community. In early planting, it's needed to combine with religious knowledge as well. Thus sensitivity and caring are formed based on the science of religion.

\section{With Behavior}

Pondok Pesantren Sidogiri is an islamic boarding school that instills in its students the value of sensitivity and caring for the society. The planting was realized by the construction of the 
BMT cooperative. With intentions to help the surrounding community to avoid usury and to replace loans from moneylenders with interest-free loans, BMT Cooperation was made, it prioritizes professional attitudes by separating pesantren management and economic management. Now Pondok Pesantren Sidogiri is not just a pesantren that teaches national books but as a place for the community to develop the economy, along with increasing public trust, the extent of the alumni network, increasing access to capital and experience. Undoubtedly, it become a part of the effective way for da'wah.

\section{With Works}

Based on our informants' information, an alumni and a religious teacher at the Pondok Pesantren Sidogiri, during the learning at the pondok pesantren, the santri was directed not only to receive learning but also to convey the knowledge that had been obtained by producing works. One example of work that has been made is Menelaah Pemikiran Agus Mustofa by A. Qusyairi Ismail and Moh. Achyat Ahmad. In these works the author uses language that is easily accepted by the community and in writing the title of the work the author chooses an interesting language, so that it can arouse people's interest in reading these works.

\section{Efforts to Make Changes in Society Without Losing Identity}

Basically, santri are expected not only to deal with education and pondok pesantren matters but also to have a good influence on the surrounding society. The influence is in the form of making changes that can provide benefits to the society from those previously far from Islamic values to the best application of Islamic values.

In making these changes, santri use methods that make people not feel forced but still have great positive impacts. It breaks the prejudice that pondok pesantren are out of date and exclusive. To be able to provide these changes, santri are equiped with activities that improve social skills and provide assistance from Kyai and teachers.

\section{Blending with Society to Make Changes}

The Santri were taught how to do da'wah (preaching of Islam) from the Wali Songo, 9 da'i (those who do da'wah) who are the first spread Islam in Java. Da'wah carried out by Wali Songo is to build a dialogue for the new culture with the old culture. Modeling this, santri are taught to be able to bring together universal values, local wisdom, and Islamic teachings, introducing Islam as rahmatan lil'alamin. Da'wah communication used by Wali Songo is psychosufistic, which is a psychological view in understanding Sufism teachings which become the framework of religious thinking and behavior (Tajuddin, 2014). This approach directs the community to religious life by adhering to the divine and human values, behaving Islamic amidst the differences and changes of era in society as an effort to preach Islam.

\section{Give Color by not Being Colored}

For some people, santri is often portrayed as old-fashioned and lacking in association. The problem aroused, in many cases, that santri are ashamed of their identity. They separate matters between inside and outside pondok pesantren. In addition, many were also reluctant to apply the knowledge they had learned to be lodged in community life.

Dealing with this, pondok pesantren educate their santri to be proud and hold fast to their santri-identity. From during their studies, to becoming alumni and serving in the community, based on several key informants' testimonies, they expressed the pride and adherence between fellow alumni of the same nature despite different places, professions, or 
generations. They are struggling in their respective fields, providing as much benefit as possible to the society while still adhering to their santri-identity.

\section{Results}

\section{Application of The Value}

\section{Creating or providing a good environment}

Self-development in the younger generation, especially in adolescence, can not be separated from the influence of the environment namely family, peers, and education (Santrock, 2011). So in the formation of identity in the Muslim young generation, a good environment must be created or provided.

Starting from family, how to educate children with adequate Islamic education from an early age, open and democratic communication, and reasonable control. In addition, adolescents identify themselves strongly with their schools and communities and tend to conform to their peers, which can be both positive and negative. So the role of parents or more mature people around them is to equip them with good and bad differentiation, to let the teenager make a decision, while doing reasonable control. In this case we can learn from pondok pesantren, how to provide adequate Islamic education, openness for students to make decisions, and the existence of rules and penalties as a form of control.

\section{Presenting good examples}

Basically, human needs for exemplary figures are derived from the tendency to imitate that has become a human character. People tend to imitate those who they feel in the same feeling with them. To prevent any bad influence from bad environment surounding, we need to set good examples or exemplary figures by ourselves.

Parents can set a good and right example by: (a) Showing good attitude, (b) Reducing bad attitude, and (c) showing affection (Nurbaity, 2017). The ultimate examplary figure in Islam, is Rasulullah, Prophet Muhammad. Parents should be able to emulate the Prophet, instill the morality of the prophet and his companion to the child by telling stories of them, and inviting children to apply good behavior from those stories.

In the School, the teacher and school staff should be the exemplary figures, like they are in the pondok pesantren. According to Abdullah Nashih Ulwan, exemplary in education is the most effective and successful way to prepare children in terms of their moral, mental and social aspects (Nurbaity, 2017). This is because education is a role model or a good idol in the eyes of children. Children will follow the behavior of the educator, imitate their morality both consciously and unconsciously. Even a form of words and actions of educators will be embedded in children and become part of children's perceptions.

\section{Familiarize sensitivity and caring starting from small things}

Social sensitivity does not appear just like that, but through experiences from the past that become habits (Nurdiansyah, 2016). So, it takes effort from the adults around the young generation of Muslims to educate them through social activities and learning processes regarding sensitivity and concern for the society.

It can start with small things, teach and directly give examples to offer help when someone needs it. In the school environment, multicultural education can also be included to increase 
social sensitivity for students. Social activities such as social service and charity can also be used as the means to develop social sensitivity and caring in young Muslims.

\section{Understanding the character of society}

Da'wah in general is an effort carried out intentionally and consciously by inviting other people to do good and prevent evil deeds (Malihah, 2014). In inviting people we should know the character of the person we are taking. When a preacher understands the character of the person being invited, the message of da'wah delivered can be received well by the person invited. The young Muslim generation, who are expected to be able to continue the da'wah relay, need to deepen their knowledge, interact with the community a lot, and listen to public complaints in an effort to understand the character of the community so the da'wah are right on target and effective.

\section{Conclusion}

Facing the problem in globalization era, Islamic Boarding School or pondok pesantren offer the solution for building young Muslim generation identity. Using 2 pondok pesantren as the main sample of this study, there are values that can be extracted and some of its aplication. Learning from the system, habit, and teaching that being done in pondok pesantren, there are 3 values that can be learned: the formation of good identity, sensitivity and caring for society, and efforts to make changes in society without losing identity. Based on those values, constructed 4 aplication: creating or providing a good environment, presenting good exemplary, familiarize sensitivity and caring starting from small things, and understanding the character of society. This result is expected to be implemented in the daily life in the society. Further reasearch will be needed in order to deepen the study and improve the aplication method so it's become more effective.

\section{References}

Alhamuddin. (2005). Pendidikan Islam Modern Ala Trimurti Pondok Modern Darussalam Gontor. At-Ta'dib, 3(2), 205-210.

BPS-Statistic Indonesia. (2018). Statistical Yearbook of Indonesia 2018. Jakarta: BPSStatistic Indonesia.

Dhofier, Z. (2009). Tradisi Pesantren: Studi Tentang Pandangan Hidup Kyai. Jakarta: LP3ES.

Directorate General of Islamic Education - Ministry of Religious Affairs of Republic of Indonesia. Statistik Pendidikan Islam Tahun Pelajaran 2014/2015.

Fasa, M. I. (2017). Gontor as The Learning Contemporary Islamic Institution Transformation toward The Modernity. Jurnal Studia Islamika, 149.

Jensen, L. A. (2003). Coming of Age in a Multicultural World: Globalization and Adolescent Cultural Identity Formation. Applied Developmental Science, 7(3), 189-196.

Indonesia, P. R. Undang-Undang Republik Indonesia Nomor 20 Tahun 2003 Tentang Sistem Pendidikan Nasional.

Mahbub. (2016). Pengaruh Pembiayaan Mudharabah terhadap pendapatan BMT UGT Sidogiri Capem Songgon Kabupaten Banyuwangi. Jurnal Hukum Islam, Ekonomi, dan Bisnis, 2(2), 65.

Malihah, L. (2014). Metode Dakwah KH. Munif Muhammad Zuhri dalam Meningkatkan Keberagaman di Lingkungan Masyarakat Girikusumo Mranggen Demak. Semarang: Undergraduate Thesis, IAIN Walisongo.

Nurbaity, M. (2017). Pembentukan Kepribadian Anak Melalui Keteladanan Orang Tua di Lingkungan Rumah Menurut Konsep Pendidikan Islam. Palembang: Universitas Islam Negeri Raden Fatah. 
Nurdiansyah, E. (2016). Improving Social Sensitivity in Society with Internalization Value of Multicultural Education. Proceedings of The 2nd SULE-IC 2016 (pp. 269-284). Palembang: FKIP, Universitas Sriwijaya.

Rofiq, M. A. (2017). Pendidikan enterpreneurship dan jiwa kemandirian santri : di Pondok pesantren Sidogiri Pasuruan dan Pondok pesantren Riadlul Jannah Pacet Mojokerto. Surabaya: Undergraduate thesis, UIN Sunan Ampel Surabaya.

Santoso, E. H. (2013). Konsep Jati Diri Manusia Menurut Ibn Miskawaih dan Relevansinya dengan Pendidikan Agama Islam. Yogyakarta: Universitas Islam Negeri Sunan Kalijaga Yogyakarta.

Santrock, J. W. (2011). Life-Span Development Thirteenth Edition. New York: McGraw-Hill.

Setyaningsih, R. (2016). Kontinuitas Pesantren dan Madrasah di Indonesia. Jurnal At-Ta'dib, $11(1), 171-172$.

Tajuddin, Y. (2014). Walisongo dalam Strategi Komunikasi Dakwah. Addin, 8 (2), 367-390. 